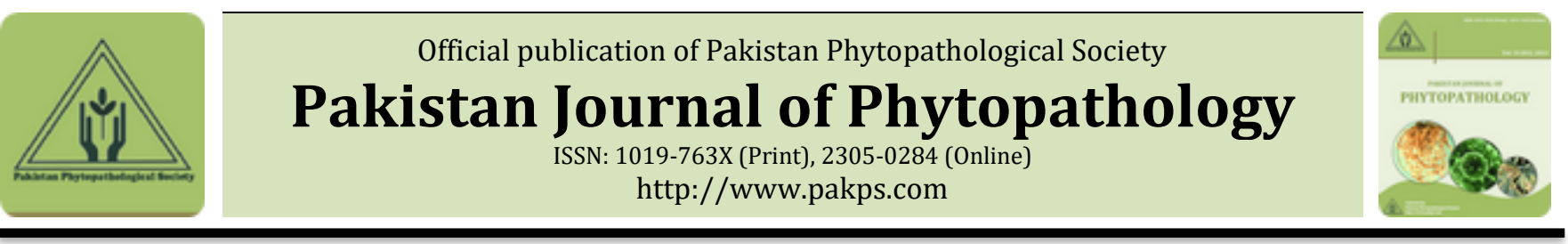

\title{
INVESTIGATION OF ARBUSCULAR MYCORRHIZAL FUNGI FROM WEEDS PLANTS GROWN IN TRITICUM AESTIVUM FIELDS IN DISTRICT CHARSADDA, PAKISTAN
}

\author{
aYaseen Khan, bTabassum Yaseen*, cKhushnood Ur Rehman, dMuhammad Noor, eUsman Jamshaid, \\ fRani Gul, bGul Nawaz, gSulaiman Shah \\ ${ }^{a}$ Key Laboratory of Plant Nutrition and Agri-environment in Northwest China, Ministry of Agriculture, \\ College of Natural Resources and Environment, Northwest A\&F University, Yangling, Shanxi, China. \\ ${ }^{\boldsymbol{b}}$ Department of Botany, Bacha Khan University, Charsadda, Khyber Pakhtunkhwa, Pakistan. \\ c Department of Botany, Islamia College Peshawar, Pakistan. \\ d Department of Agriculture, Hazara University, Khyber Pakhtunkhwa, Pakistan. \\ e Department of Soil and Environmental Sciences, Muhammad Nawaz Shareef, University of Agriculture Multan, Pakistan. \\ fDepartment of Agriculture, Bacha Khan University, Charsadda, Pakistan.
}

${ }^{g}$ Department of Botany, University of Malakand Chakdara, Khyber Pakhtunkhwa, Pakistan.

\section{A B S T R A C T}

Arbuscular mycorrhizal (AM) symbiosis is a reciprocal association between fungi and more than $80 \%$ of terrestrial plants, and the association play an important role in plant growth and development. Arbuscular mycorrhizal fungi (AMF) colonization have been explored in various crops such as wheat and maize, however, AMF colonization in weeds has been poorly investigated. In order to explore the AMF colonization in weeds grown in wheat fields, a study has been conducted in which we identified first the weeds species and then AMF spores and colonization in wheat (Triticum aestivum L.) fields at four localities viz Ghazgai, Palosa, Sardeheri and Mangha dargi in District Charsadda, Khyber Pakhtunkhwa, Pakistan. Fifteen species belonging to 12 families were found distributed as wheat's weeds in the study areas. The most important families in terms of species representation were Asteraceae (3 genera and 3 species) followed by Fabaceae (1 genus and 2 species) Euphorbiaceae, Cryophyllaceae, Leguminaceae, Papaveraceae, Poaceae, Brassicaceae, Cannabinaceae, Chenopodiaceae, Convolvulaceae and Polygonaceae. The increase of AMF root colonization was high in Mangha dargi (25-119 \%) followed by Ghazgai (4090\%), Sardeheri (34-80\%) and Palosa (24-80\%). Moreover, Great AMF (TSD) per hundred gm-1 of soil abundance were recorded in Ghazgai (65-131 gm-1) followed by Mangha dargi (40-119 gm-1), Palosa (46-115 gm-1) and lowest was in Sardheri (40-107 gm-1). The present investigation highlights the AMF colonization, identification, classification and documentation of weeds in different localities of district Charsadda, Pakistan.

Keywords: Arbuscular mycorrhizal fungi, Titicum aestivum, Weeds, District Charsadda

\section{INTRODUCTION}

Arbuscular mycorrhiza (AM) is symbiotic association between Arbuscular mycorrhizal fungi (AMF) and plant roots, which provides and shared advantages to both partners in terms of nutrients. Approximately, $85-90 \%$

\section{Submitted: September 04, 2020}

Revised: December 07, 2020

Accepted for Publication: December 21, 2020

* Corresponding Author: Tabassum Yaseen

Email: tabassumyaseen@bkuc.edu.pk

(C) 2017 Pak. J. Phytopathol. All rights reserved. of the land plants can be colonized by AM fungi as the remaining are weeds (Jordan et al., 2000) which are not relying on AMF for nutrient uptake presumably due to deep and extensive rooting system (Wang and Qiu, 2006; Brundrett, 2009). Although AMF has been used for weeds control (Cameron, 2010; Jordan et al., 2000), but the exact mechanism how they interact with weeds is not known. There are reports that AMF can change the structure and nature of weeds. It was further documented that these fungi are not always detrimental to weeds plants but minimize the crop yield loss arising 
from weeds plants and reduces the negative effects of weeds on crop plants (Jordan et al., 2000). AM Fungi have been reported to play a role in ecological relationship of weeds as they can affect the weeds growth without influencing the crop plants growth (Jordan et al., 2000). However, the colonization and spore density of AMF is still not well explored.

Weeds are plants grown out of place or unintentionally which compete with our major crops for nutrients, light and other requirements. The yield loss due to weeds has been estimated to be 34\% every year (Oerke, 2006) and in some cases even 45-95\% (Ampong and De Datta, 1991) despite using control measures which is alarming. About 200 weeds have been reported to develop resistance against various herbicides due to excessive application of herbicides in our field crops. Herbicides are not supposed to be applied for weeds control in organic farming, which is a sort of farming without applying any chemical, and mostly employ cultural control methods for weeds control. The organic farming is aimed to avoid harming of natural environment by exploiting the traditional or cultural control methods (Basker, 2009).

The colonization of crop plants by AMF may be adversely affected in case of mechanical control of weeds possibly due to hyphal damages which has not been observed in case of herbicides application (Brito et al., 2013). In another control method termed as bio control living organism are being used for weeds control mostly as foliar pathogens. The idea of using living microbes for weeds control is fascinating but it should have been included soil microorganisms like rhizobacteria and AMF etc. having the potential for weeds control directly or indirectly (Boyetchko, 1996). Apart from this, tissue culture based approaches were used for observing bacteria, which is considered as one of the bio control method of weeds (Souissi et al., 1994).

Here, we aimed to identify the weeds species in Titicum aestivum field, and then we further explored the AMF spore density and colonization in weeds. The objects of this work were: (1) to explore the weeds species abundance in Titicum aestivum field; and (2) to uncover the AMF colonization in weeds in different localities of district charsadda, Pakistan.

\section{MATERIALS AND METHODS}

Study Site: Charsadda average temperature is about $22.5^{\circ} \mathrm{C}$. The average rainfall in this part of Khyber Pakhtunkhwa has been reported to be $460 \mathrm{~mm}$. The month June is normally the driest and warmest one with mean temperature of $33.3^{\circ} \mathrm{C}$ receiving approximately $11 \mathrm{~mm}$ rainfall (Anonymous, 1998). The lowest mean temperature has been reported in January, which is about $10.4{ }^{\circ} \mathrm{C}$. The land of this region is fertile and used for growing agriculturally important crops like Wheat, maize, tobacco, Sugarcane and Sugar beet etc.

Research sites: The study area was designed into four localities:

1. Ghazgai, 2. Palosa, 3. Sardeheri, s4. Mangha dargi

These localities were selected for field analysis and collection of weeds.

Collection of Weeds: Weeds samples were collected from four different area (Ghazgai, Palosa, Sardeheri and Mangha dargi) of study considering, habitat, life form, phonological status, and abundance. Collections of weed samples were based on random sampling during different time periods of wheat growth.

Preservation: After collection of all specimens were properly shady dried under room temperature in open space. The dried specimens were than mounted and preserved on herbarium sheet (Judd, 2002).

Identification of weeds: The total collected specimens were then subjected to identification. Weed samples were identified with the help of flora of Pakistan (Nasir et al., 1972; Nasir et al., 1995).

Soil and Root Sampling of weeds species: The Survey was undertaken at 4 different sites located in Charsadda city. In each Location three cultivated fields was selected. In each field Root and soil samples of weeds plants were collected randomly. From each site, 3-4 healthy wheat plants were collected along with rhizospheric soil and roots at different stages (vegetative -fruiting stages). Roots and rhizosphere soil was dug out with a trowel at a depth of $0-15 \mathrm{~cm}$ after scrapping away the top $1 \mathrm{~cm}$ layer of soil. Samples were collected randomly from different site in each field, pooled and homogenized. Soil samples along with secondary and tertiary roots of three individual fields for fifteen weeds plants were collected during course of investigation from 2015. Rhizospheric soils (about $100 \mathrm{gm}$ ) were air dried for 2-3 weeks, and then stored in sealed plastic bags at room temperature.

Identification of AMF spores: The identification of these fungi was done by following the manual of (Schenck \& Perez, 1990) and was also compared with reference species description demonstrated by INVAM (International culture collection of vesicular arbuscular 
mycorrhizal fungi, 2014). For the characterization of AM fungi, various characteristics of spores such as spore morphology, shape, colour and size were studied.

Assessment of root colonization of weeds: For assessment of root colonization of weeds, the procedure of (Giovannetti and Mosse, 1980) was used. For Microscopic study, three fragments each about $1 \mathrm{~cm}$ long was randomly chosen. Morphology of AMF entophyte was studied and expressed in percentage (\%). The percent infection was calculated as follow:

\section{Extraction and isolation of Spores from weeds:}

$$
\text { Percent colonization }=\frac{\text { Total number of colonized root segment }}{\text { Total number of colonized root segment examined }} \times 100
$$

\section{RESULTS AND DISCUSSION}

Root colonization and Spore diversity in weeds: In the present study presence of AMF root colonization were investigated shown in Tables (2 \& 4) and Figures (1-4 and 6). Our study also observed an increase in AMF root colonization over the wheat-growing season in all localities of Charsadda (Figure 1-4). The increase of AMF root colonization (TRC) percentage was highest in Mangha dargi
Rhizospheric soil samples were collected of wheat at vegetative and fruiting stages. $300 \mathrm{gm}$ sample of rhizospheric soil was taken from different fields of the wheat plant at a depth $15-20 \mathrm{~cm}$. Wet sieving and decanting technique of (Gerdemann and Nicolson, 1963). Wet sieving techniques was used to extract the spores from collected soil samples, sieving techniques include different sizes; $30 \mu \mathrm{m}, 50 \mu \mathrm{m}$, and $100 \mu \mathrm{m}$. The spores were introduced onto slide in drop of glycerine. Spore density was calculated using known method demonstrated by (Stahl and Christensen 1982) which can be defined average number of spores per 100gram of soil.

(25-119\%) followed by the others localities of Charsadda Ghazgai (40-90 \%), Sardeheri (34-80 \%age) and Palosa (24-80\%age). Our results are supported by (Bilalis et al., 2011) who demonstrated that colonization of weeds by AM fungi vary in response to different weeds. No effects were observed on the growth of non-competitive weeds by AMF symbiosis. Positive effects on the growth of competitive weeds was observed with the presence of AMF.

Table 1. General information about collected weeds from wheat crops of District Charsadda.

\begin{tabular}{|c|c|c|c|c|c|}
\hline S.no & Name of weeds & Family & Group & Sub-group & Growth phase \\
\hline 3 & Medicago sativa & Leguminaceae & Angiosperm & Dicotyledon & Fruiting \\
\hline 5 & Cynodon dactylon & Poaceae & Angiosperm & monocotyledon & Vegetative \\
\hline 6 & Conyza canadensis & \multirow[t]{2}{*}{ Asteraceae } & Angiosperm & Dicotyledon & Vegetative \\
\hline 7 & Parthenium hysterophorus & & Angiosperm & Dicotyledon & Fruiting \\
\hline 9 & Capsella bursa-pastoris & Brassicaceae & Angiosperm & Dicotyledon & Flowering \\
\hline 10 & Canabis sativa & Cannabinaceae & Angiosperm & Dicotyledon & Fruiting \\
\hline 11 & Chenopodium album & Chenopodiaceae & Angiosperm & Dicotyledon & Fruiting \\
\hline 12 & Convolvulus arvensis & Convolvulaceae & Angiosperm & Dicotyledon & Fruiting \\
\hline 13 & Vicia faba & \multirow[t]{2}{*}{ Fabaceae } & Angiosperm & Dicotyledon & Flowering \\
\hline 14 & Vicia sativa & & Angiosperm & Dicotyledon & Fruiting \\
\hline
\end{tabular}

Much variation was observed in the external hyphae, that though maize presented a negative mycorrhizal internal hyphae, arbuscules and vesicles in all studied sites, which show diversity of AMF population in weeds species (Fig.5). The diversity of agronomical important AM fungal species can be retained with thse help of weeds (Vatovec et al., 2005). Significant increase in number of AMF spores was documented with increasing number of weeds species (Chen et al., 2004). (Rillig, 2004) demonstrated reduced AMF hyphal length in those areas having dense population of invasive mycorrhizal weed as compared to area getting chemical or other management practices. (Veiga, 2012) observed growth response when grown alone. It was insensitive to AMF in the presence of weeds, while the coexisting weed species grew lesser when colonized by AMF. It was proposed that maize forms more beneficial symbiosis with AM fungi than other tested weed species. Our study also observed an increase in AMF spore density and over the wheat growing season in all localities of Charsadda shown in (Figure 1- 4 and 5) and AMF diversity Table (3). Great AMF (TSD) per hundred $\mathrm{gm}^{-1}$ of soil abundance were recorded in Ghazgai (65-131 $\mathrm{gm}^{-1}$ ) followed by Mangha dargi (40-119 $\mathrm{gm}^{-1}$ ), Palosa (46-115 
$\left.\mathrm{gm}^{-1}\right)$ and lowest in Sardheri (40-107 $\left.\mathrm{gm}^{-1}\right)$ results agree with (Vatovec et al 2005) stating that AMF not always adversely affect weeds growth but some weeds species may affect the diversity and abundance of AM fungi.
Reduced crop losses have been reported in case of positive interaction of weeds and AMF, which arises from weeds. It has also positive effects on soil microbial community composition and soil property.

Table 2. AMF colonization percentage in different weeds of wheat crops of District Charsadda.

\begin{tabular}{|c|c|c|c|c|c|c|}
\hline S.no & Name of weeds & Family & IH. (\%) & EH. (\%) & Arb. (\%) & Ves. (\%) \\
\hline 1 & Euphorbia helioscopia & Euphorbiaceae & 20 & 32 & 40 & 44 \\
\hline 3 & Medicago sativa & Leguminaceae & 45 & 30 & 33 & 40 \\
\hline 5 & Cynodon dactylon & Poaceae & 44 & 50 & 55 & 74 \\
\hline 6 & Conyza canadensis & \multirow[t]{2}{*}{ Asteraceae } & 44 & 45 & 65 & 70 \\
\hline 7 & Parthenium hysterophorus & & 40 & 40 & 62 & 79 \\
\hline 9 & Capsella bursa-pastoris & Brassicaceae & 0 & 0 & 0 & 0 \\
\hline 10 & Canabis sativa & Cannabinaceae & 115 & 10 & 10 & 22 \\
\hline 11 & Chenopodium album & Chenopodiaceae & 10 & 13 & 15 & 20 \\
\hline 12 & Convolvulus arvensis & Convolvulaceae & 30 & 40 & 44 & 58 \\
\hline 13 & Vicia faba & Fabaceae & 40 & 40 & 54 & 69 \\
\hline
\end{tabular}

Table 3. Spore density and diversity in different weeds of wheat crops of District Charsadda.

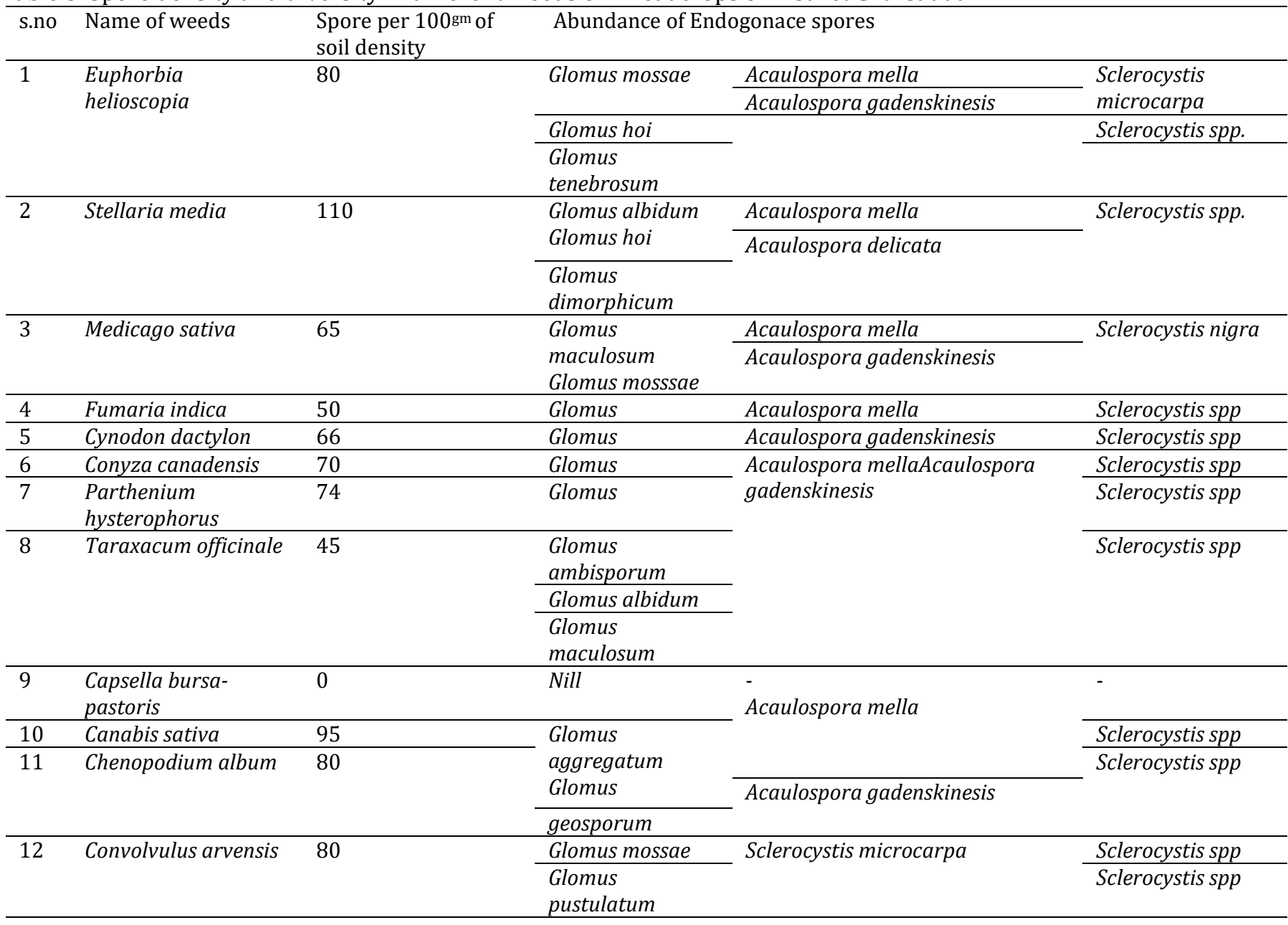




\begin{tabular}{llllll}
\hline 13 & Vicia faba & 85 & Glomus & Acaulospora mella & Sclerocystis spp \\
\hline 14 & Vicia sativa & 60 & Glomus & & Sclerocystis spp \\
\hline 15 & Rumex nepalensis & 75 & Glomus & Acaulospora gadenskinesis & Sclerocystis spp \\
& & fasiculatum & \\
& & Glomus albidum & \\
& & Glomus hoi & & \\
\hline
\end{tabular}

Table 4. Arbuscular mycorrhizal infection Dominancy in different four Localities of district Charsadda.

\begin{tabular}{|c|c|c|c|c|c|c|c|c|c|}
\hline \multirow[t]{2}{*}{ S. No } & \multirow[t]{2}{*}{ Species Name } & \multicolumn{2}{|c|}{ Ghazgai } & \multicolumn{2}{|c|}{ Palosa } & \multicolumn{2}{|c|}{ Sardeheri } & \multicolumn{2}{|c|}{ Mangha dargi } \\
\hline & & TSD & TRC $\%$ & TSD & TRC\% & TSD & TRC $\%$ & TSD & TRC $\%$ \\
\hline 1 & Euphorbia helioscopia & 112 & 40 & 100 & 72 & 107 & 56 & 95 & 82 \\
\hline 2 & Stellaria media & 125 & 35 & 110 & 24 & 90 & 80 & 100 & 80 \\
\hline 3 & Medicago sativa & 100 & 55 & 69 & 44 & 85 & 73 & 119 & 78 \\
\hline 4 & Fumaria indica & 123 & 60 & 115 & 34 & 49 & 70 & 80 & 90 \\
\hline 5 & Cynodon dactylon & 110 & 70 & 87 & 62 & 59 & 65 & 70 & 40 \\
\hline 6 & Conyza canadensis & 90 & 60 & 46 & 61 & 50 & 55 & 74 & 51 \\
\hline 7 & $\begin{array}{l}\text { Parthenium } \\
\text { hysterophorus }\end{array}$ & 80 & 80 & 100 & 54 & 68 & 50 & 70 & 66 \\
\hline 8 & Taraxacum officinale & 75 & 45 & 56 & 60 & 40 & 48 & 70 & 80 \\
\hline 9 & $\begin{array}{l}\text { Capsella bursa- } \\
\text { pastoris }\end{array}$ & 65 & 74 & 50 & 80 & 45 & 34 & 65 & 44 \\
\hline 10 & Canabis sativa & 110 & 70 & 80 & 40 & 60 & 40 & 80 & 34 \\
\hline 11 & Chenopodium album & 123 & 90 & 85 & 60 & 75 & 45 & 83 & 62 \\
\hline 12 & Convolvulus arvensis & 131 & 40 & 92 & 35 & 77 & 55 & 100 & 23 \\
\hline 13 & Vicia faba & 100 & 60 & 76 & 55 & 60 & 80 & 25 & 26 \\
\hline 14 & Vicia sativa & 85 & 74 & 65 & 35 & 54 & 78 & 40 & 66 \\
\hline 15 & Rumex nepalensis & 90 & 82 & 55 & 55 & 40 & 70 & 90 & 75 \\
\hline
\end{tabular}

TSD (total spore density per 100gm of soil) TRC (total root colonization percentage)

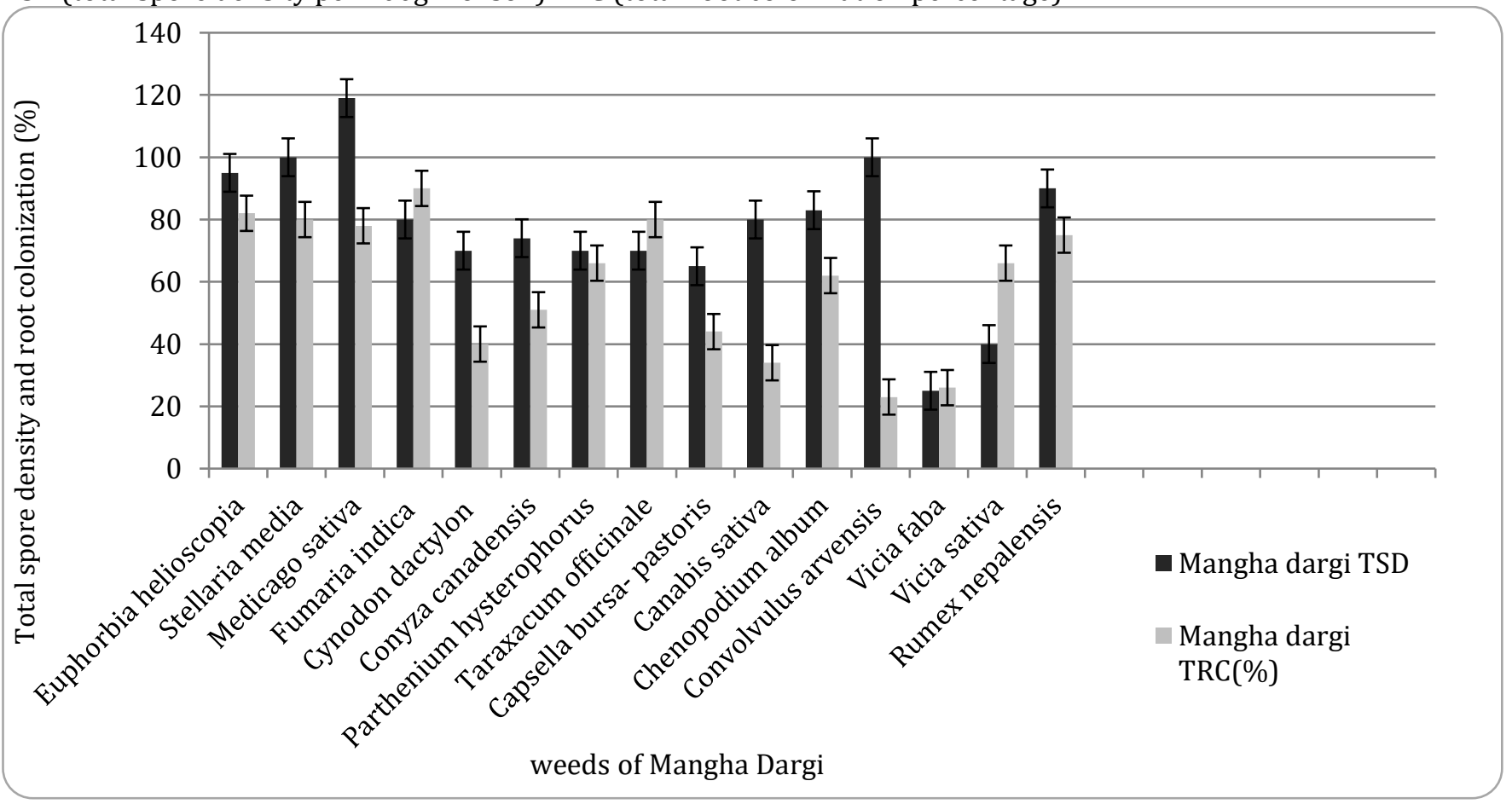

Figure 1. Total spore density (TSD) and Total root colonization (TRC) percentage in Mangha Dargi of district Charsadda. 


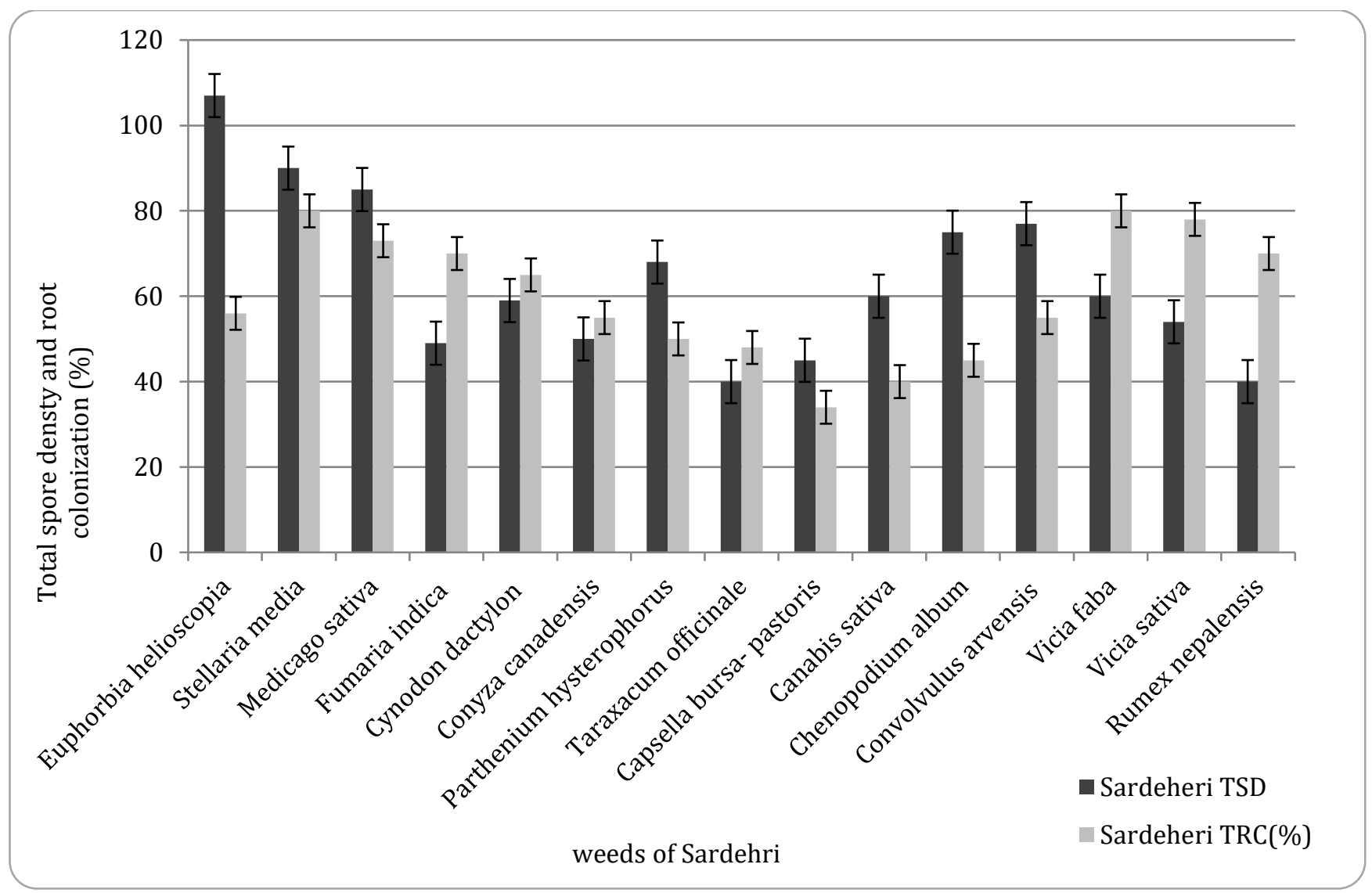

Figure 2. Total spore density (TSD) and total root colonization (TRC) percentage in Sardeheri of district Charsadda

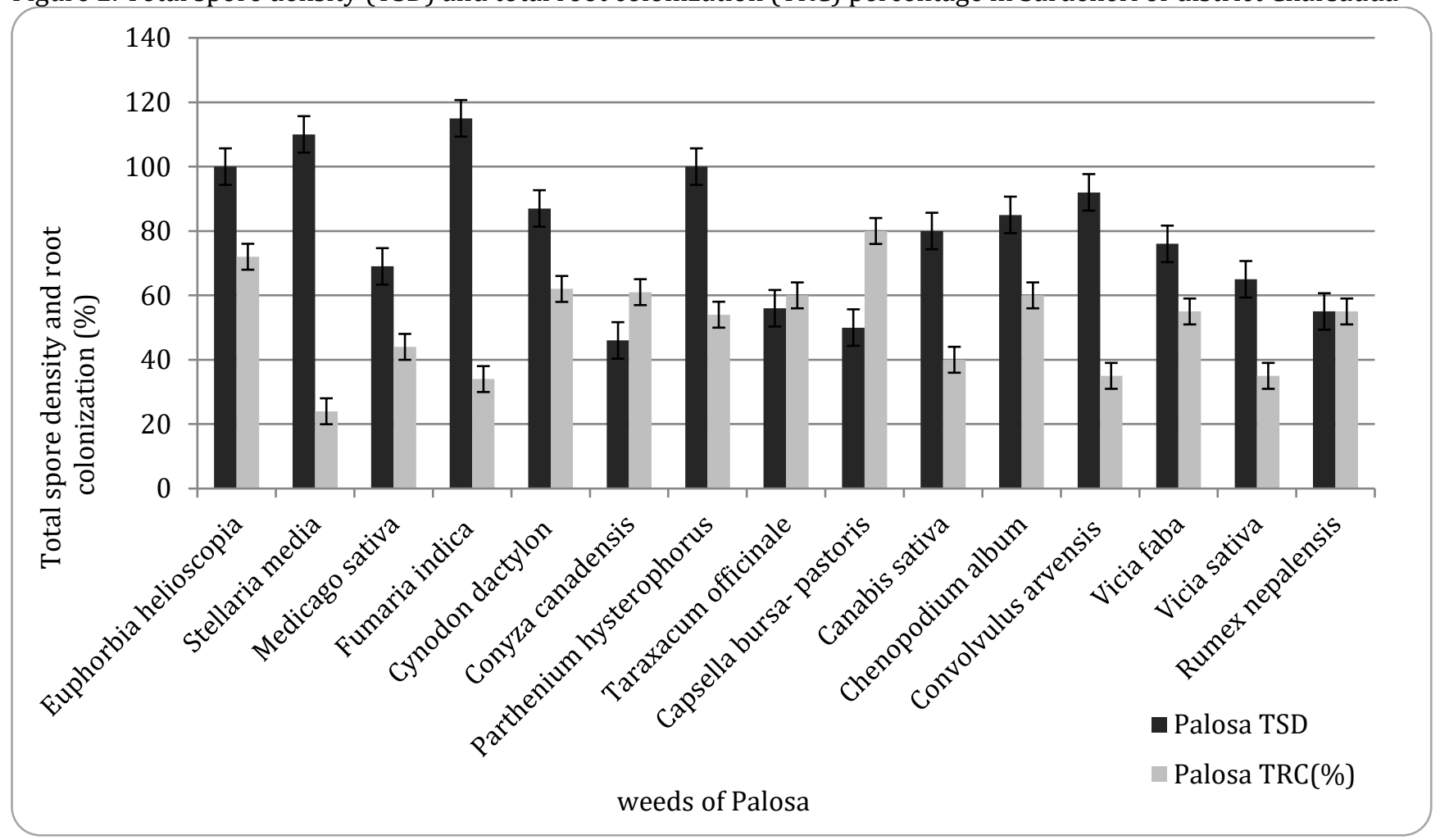

Figure 3. Total spore density (TSD) and total root colonization (TRC) percentage in Palosa of district Charsadda 


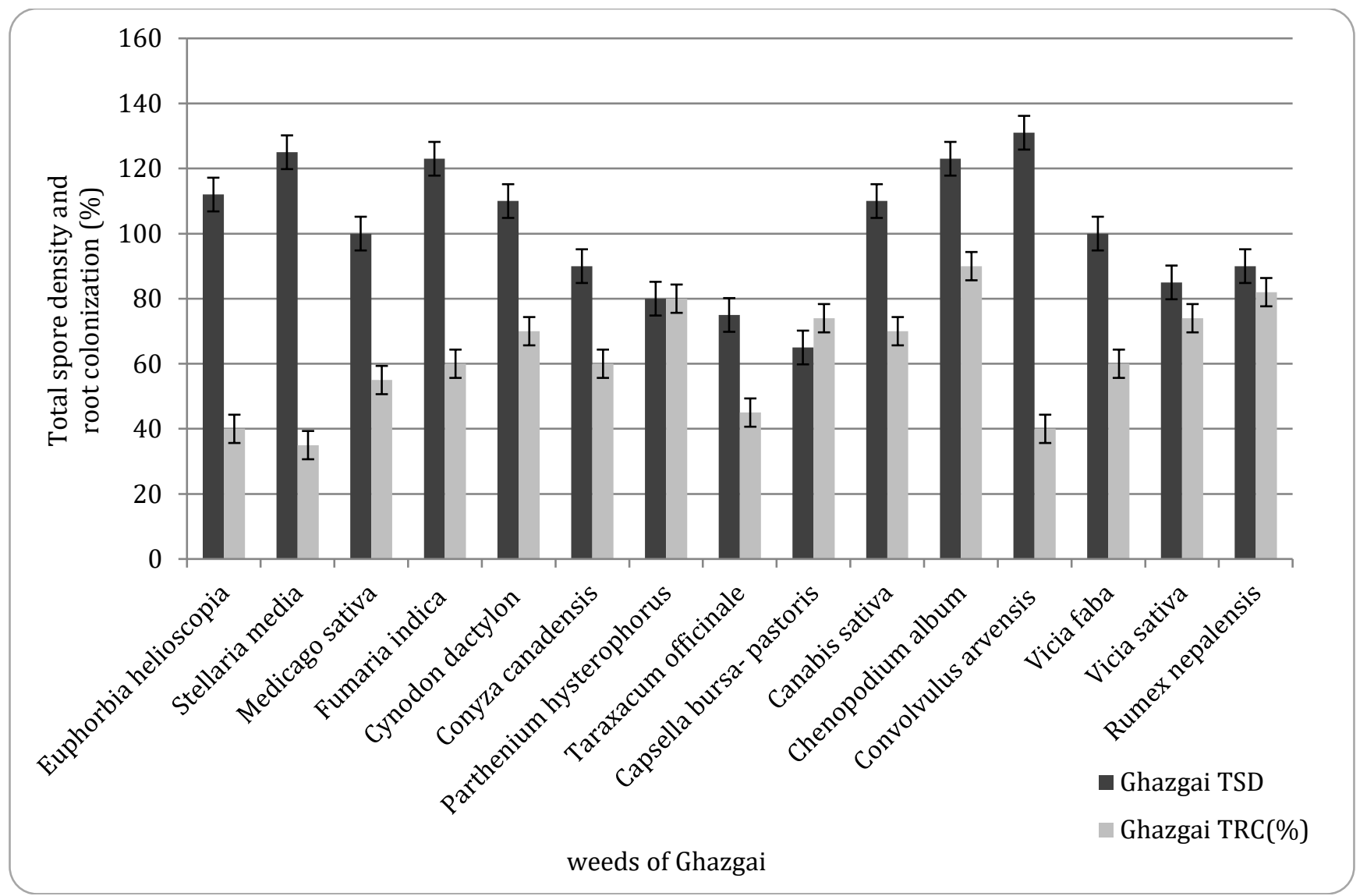

Figure 4. Total spore density (TSD) and Total root colonization (TRC) percentage in Ghazgai of district Charsadda

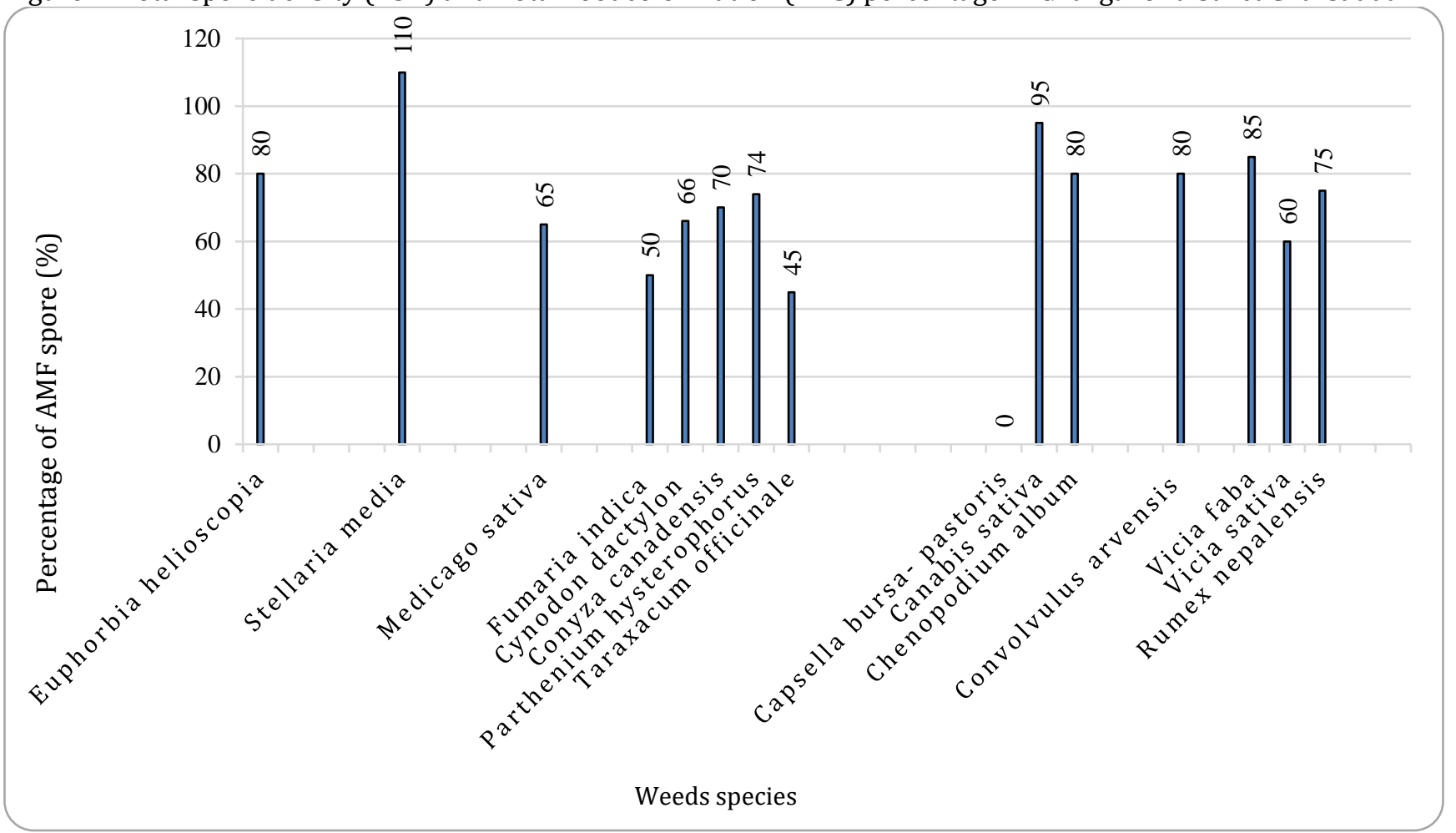

Figure 5. Spore diversity and density in different weeds species 


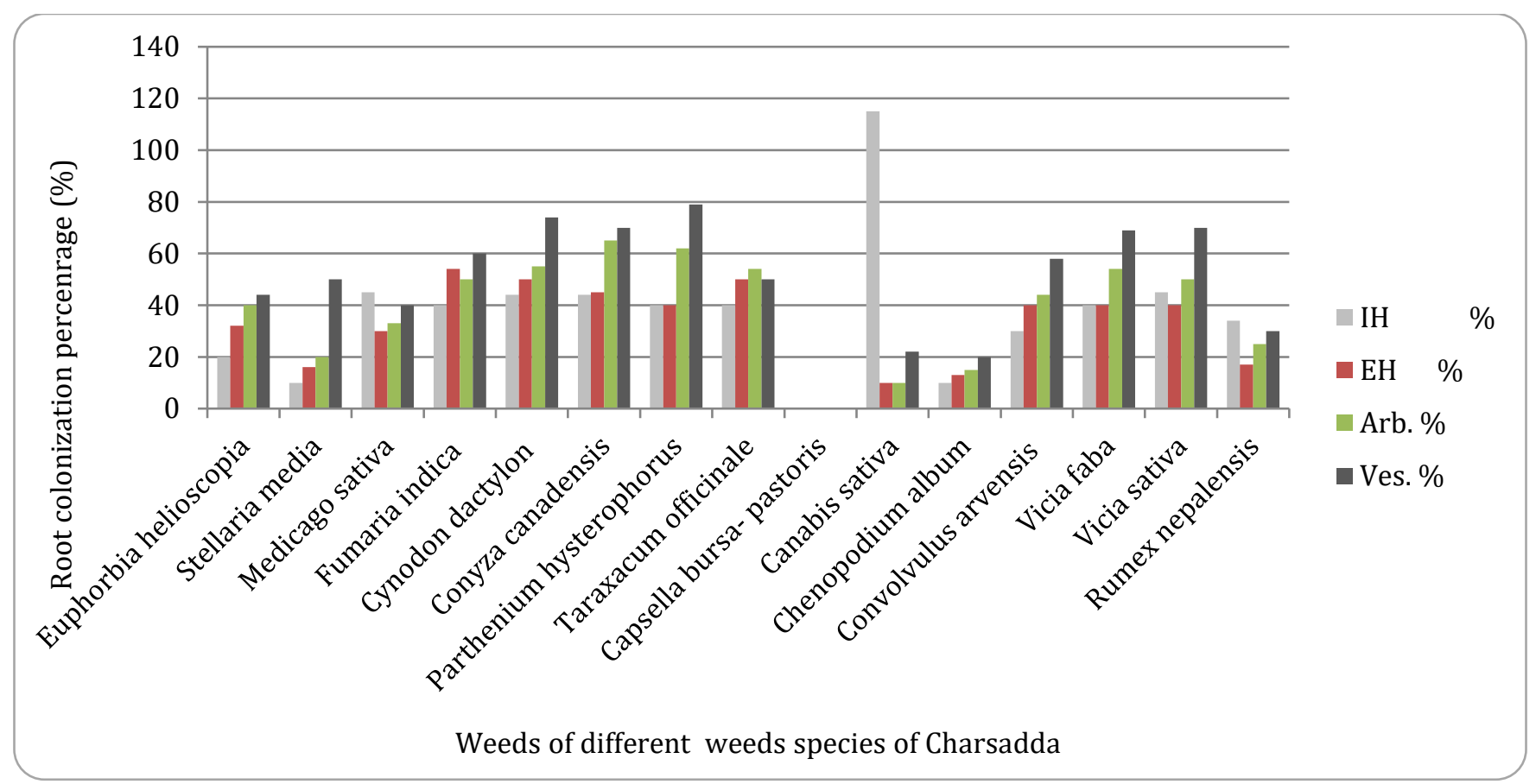

Figure 6. Root colonization by AMF structures IH (internal hyphae), EH. (External hyphae), Arb. (Arbuscules) and Ves. (Vesicles) in different weeds species.

\section{CONCLUSION}

It is concluded from our results that the most abundant weed family is Asteraceae followed by other families in wheat field. It is also cleared that the diversity of AMF spore density and root colonization varied from species to species, family to family and also affected by host plant growth stages (flowering/ vegetative stage). There is a specificity of AMF, natural diversity of AM fungi in the soil differ from species to species and differently influence root colonization and spore density. Spore density when studied in different location of district Charsadda, indicated that the dominant AMF area was Mangha dargi followed other localities which indicate that AMF root colonization varied by place to place. Furthermore, more research is required to explore the AMF colonization in weeds in other crops field.

Abbreviations: AMF (Arbuscular Mycorrhizal Fungi), TSD (Total Spore Density), TRC (Total Root Colonization), IH (Internal Hyphae), EH (External Hyphae)

\section{FUNDING}

National research program for universities project $\mathrm{Nrpu} / \mathrm{Hec} / \mathrm{R} \& \mathrm{D} / 9344$

\section{REFERENCES}

Ampong-Nyarko, K. and S. K. De Datta. 1991. A handbook for weed control in rice. International Rice
Research Institution, 1-49.

Anonymous. 1998. District Census Report of Charsadda, PCO, Govt. of Pakistan.

Basker, D. 1992. Comparison of taste quality between organically and conventionally grown fruits and vegetables. American Journal of Alternative Agriculture, 7: 129-136.

Bilalis, D., A. Karkanis, A. Konstantas, S. Patsiali and V. Triantafyllidis. 2011. Arbuscular mycorrhizal fungi: a blessing or a curse for weed management in organic olive crops. Australian Journal of Crop Science, 5: 858.

Boyetchko, S. M. 1996. Impact of soil microorganisms on weed biology and ecology. Phytoprotection, 77: 4156.

Brito, I., M. Carvalho and M. J. Goss. 2013. Soil and weed management for enhancing arbuscular mycorrhiza colonization of wheat. Soil use and Management, 29: 540-546.

Brundrett, M. C. 2009. Mycorrhizal associations and other means of nutrition of vascular plants: understanding the global diversity of host plants by resolving conflicting information and developing reliable means of diagnosis. Plant and Soil, 320: 37-77.

Cameron, D. D. 2010. Arbuscular mycorrhizal fungi as (agro) ecosystem engineers. Plant and Soil, 333: 1-5. 
Chen, X., J. Tang, Z. Fang and K. Shimizu. 2004. Effects of weed communities with various species numbers on soil features in a subtropical orchard ecosystem. Agriculture, Ecosystems \& Environment, 102: 377388.

Gerdemann, J. and T. H. Nicolson. 1963. Spores of mycorrhizal Endogone species extracted from soil by wet sieving and decanting. Transactions of the British Mycological society, 46: 235-244.

Giovannetti, M. and B. Mosse. 1980. An evaluation of techniques for measuring vesicular arbuscular mycorrhizal infection in roots. New Phytologist, 84: 489-500.

Jordan, N. R., J. Zhang and S. Huerd. 2000. Arbuscularmycorrhizal fungi: potential roles in weed management. Weed Research-Oxford, 40: 397-410.

Khan, M. N., F. Hadi, A. Razaq and S. M. Shah. 2017. Utilitarian aspects of weeds and their ecological characteristics in Ochawala valley, District Charsadda, Pakistan journal of agricultural sciences, 5: 182-189.

Nasir, E., Ali, S. I., \& Stewart, R. R. (1972). Flora of West Pakistan: an annotated catalogue of the vascular plants of West Pakistan and Kashmir. Fakhri, 102.

Nasir, Y. J., R. A. Rafiq and T. J. Roberts. 1995. Wildflowers of Pakistan. Oxford university press. Information System Division, National Agricultural Library, 264266.

Oerke, E. 2006. Crop losses to pests. The Journal of Agricultural Science, 144: 31-43.

Phillips, J. M. and D. Hayman. 1970. Improved procedures for clearing roots and staining parasitic and vesicular-arbuscular mycorrhizal fungi for rapid assessment of infection. Transactions of the British Mycological Society, 55: 158-161.

Rillig, M. C. 2004. Arbuscular mycorrhizae and terrestrial ecosystem processes. Ecology Letters, 7: 740-754.

Schenck, N. and Y. Perez. 1990. Manual for the Identification of VAM Fungi. 3rd. Synergistic Publication, Gainesville, Fl,USA, 3-17.

Souissi, T. and R. J. Kremer. 1994. Leafy spurge (Euphorbia esula) cell cultures for screening deleterious Rhizobacteria. Weed Science, 42: 310-315.

Stahl, P. D. and M. Christensen. 1982. Mycorrhizal fungi associated with Bouteloua and Agropyron in Wyoming sagebrush-grasslands. Mycologia, 74: 877-885.

Trappe, J. M. 1982. Synoptic keys to the genera and species of Zygomycetous mycorrhizal fungi. Phytopathology, 72: 1102-1108.

Vatovec, C., N. Jordan and S. Huerd. 2005. Responsiveness of certain agronomic weed species to arbuscular mycorrhizal fungi. Renewable Agriculture and Food Systems, 20: 181-189.

Veiga, R. 2012. Biological weed control with soil fungi. Antagonistic effects of arbuscular mycorrhizal fungi on the growth of weeds. Dissertation. Utrecht University Repository.

Wang, B. and Y.-L. Qiu. 2006. Phylogenetic distribution and evolution of mycorrhizas in land plants. Mycorrhiza, 16: 299-363.

\begin{tabular}{|c|c|}
\hline Contribution of Autho & \\
\hline Yaseen Khan & : Carried out experimental work \\
\hline Tabassum Yaseen & : Supervised the work and wrote the paper \\
\hline Khushnood Ur Rehman & : Provided the research materials \\
\hline Muhammad Noor & : Provided the research materials \\
\hline Usman Jamshaid & : Helped in execution of field trial \\
\hline Rani Gul & : Helped in execution of field trial \\
\hline Gul Nawaz & : Prepared graphs \\
\hline Sulaiman Shah & : Analyzed data statistically \\
\hline
\end{tabular}

